\title{
The transition from sustainable to regenerative development
}

\author{
May East \\ UNITAR Fellow, Chief Executive of Gaia Education, Edinburgh, Scotland, UK \\ E-mail address: may.east@gaiaeducation.org
}

\begin{abstract}
There is an international consensus that our generation is facing a convergence of multiple crises and that the same mindset that has created this convergence is incapable of solving it. Paradigms evolve and shift when the prevailing frameworks are unable to explain and address new anomalies in development processes. For some, the sustainability concept fails to offer guidance on how to arbitrate between the conflicting drivers of economic growth, planetary boundaries and social justice. The concept of nine Planetary Boundaries (PB) involving Earth system processes which humanity should aim to operate safely, include global biogeochemical cycles (nitrogen, phosphorus, carbon and water), the major physical circulation systems of the planet (the climate, stratosphere and ocean systems), marine and terrestrial biodiversity and anthropogenic forcing (aerosol loading and chemical pollution). According to recent research, four of the nine planetary boundaries had been crossed due to the adverse impacts of human activities. The solution is the regenerative concept manifested in the Sustainable Development Goals (SDGs), which implies locally adaptable, resource conserving policies, activities and products, carefully tailored to the biocultural uniqueness of each location. Regenerative design is grounded in a deep understanding of the integral and interdependent nature of living systems, providing viable management solutions for economies in order to not exceed the environmental, social and economic carrying capacity of ecosystems.
\end{abstract}

Keywords - sustainable development, regenerative development, Earth System Science, planetary boundaries, carrying capacity, natural resources, Sustainable Development Goals

"The Earth system behaves as a single, self-regulating system comprised of physical, chemical, biological and human components."

2001 Amsterdam Declaration on Earth System Science

\section{Introduction}

There is an international consensus that our generation is facing a convergence of multiple crises and that the same mindset that has created this convergence is incapable of solving it. Kuhn (1962) wrote that paradigms evolve and shift when the prevailing frameworks are unable to explain and address new anomalies in the field. It is likely we are at the threshold of a 'great divide' between paradigms in history (IONS, 2015), in science (Keeping, 2012) and our relationship with the living Earth (Lovelock, 2003).

Over the last decades, policy makers, researchers and scientists, businesses and practitioners have been grappling with the critical question - how to make the world prosperous, fair and also environmentally sustainable, so that the human population and economy do not overrun the physical planet itself. For some, the sustainability concept fails to offer guidance on how to arbitrate between the conflicting drivers of economic growth, planetary boundaries and social justice (Rockström and Sachs, 2013).

Foucault (1979) argues that discourse creates frameworks which structure social life through which power is exercised. Since the Earth Summit in 1992, the limits of the planetary environment have been framed and described using various concepts, for example, 'carrying capacity' defined by Giampietro et al. (1992) as the limit to the number of humans the Earth can support in the long-term without damage to the environment. Other concepts include 'tipping points', 'footprints' and 'sustainable consumption and production' (SCP). Adopted in 2002 at the World Summit on Sustainable Development (WSSD), SCP was then understood as an essential requirement for the promotion of sustainable development within the carrying capacity of ecosystems, for which developed countries, in particular, should provide leadership (UNEP, 2002). 
A paper by Rockström et al. (2009) introduced the concept of Planetary Boundaries (PB) involving Earth system processes which humanity should aim to operate safely within. The nine planetary boundaries include global biogeochemical cycles (nitrogen, phosphorus, carbon and water); the major physical circulation systems of the planet (the climate, stratosphere and ocean systems); marine and terrestrial biodiversity; and anthropogenic forcing (aerosol loading and chemical pollution). In 2015 an international team of leading Earthsystems scientists published an update of the PB framework in the Journal Science and claimed that four of the nine planetary boundaries had been crossed due to human activity (Stephen et al., 2015).

A key message of the science-based PB framework is that the intensity of economic activity combined with technologies that are disruptive to the planet's natural processes are destabilising the Earth's fundamental dynamics such as the climate system, the water cycle, the nitrogen cycle and the ocean chemistry. Dearing et al. points out (2014, p.227) 'it is easier to define ecological boundaries retrospectively when they have already been crossed', while Balmford (2011) argues that the process of setting boundaries can only be effective if early warning systems, model simulations and the ability to pre-determine systemic change are put in place.

A discussion paper by Raworth (2012) set out a revised framework for sustainable development combining the concept of planetary boundaries with the idea of human welfare boundaries. The twelve dimensions of the social welfare known as the 'OXFAM doughnut', focused on the social justice requirements underpinning sustainability (Dearing et al., 2014) and converged environmental and social boundaries into one single framework. Lovelock reinforces this argument when suggesting that the metaphor of a living Earth serve as a reminder that 'human rights are constrained by the needs of our planetary partners' (2003, pp 769-770).

The broad range of definitions and multiple interpretations of the sustainable development concept in use today demonstrate several serious internal flaws that must be addressed before it is widely adopted as the primary global 'development' approach (Hove, 2004). While for some theorists sustainability is seen as a moving target for which it is not worth the effort to establish precise measurements (Hempel, 1999), for others, boundaries need metrics as much as a compass needs a needle (Raworth, 2012). Despite its ambiguity and lack of consensual measurement, the international community has adopted the concept of sustainability enshrined through Agenda 2030 (UN, 2015) and its 17 Sustainable Development Goals (SDGs), 164 Targets and 230 individual indicators adopted by all UN member states in 2015.

\section{SDGs: a new global framework}

The international process to develop a set of universal Sustainable Development Goals originated during Rio +20 , the UN Conference on Sustainable Development, as a new global framework to address the convergence of multiple crises and re-direct humanity towards a sustainable pathway.

There followed a three-year process involving the UN Member States, 83 national surveys engaging over seven million people, and thousands of actors from the international community, making it the most significant consultation ever in UN history. The goals have thus been heavily negotiated and have a broad legitimacy amongst all parties (Lunn et al. 2015).

The breadth and depth of the SDGs is unprecedented. The goals address issues related to poverty, hunger, health, education, energy, work, industry, inequalities, cities, consumption, climate, ocean life, ecosystems, peace and partnership, but, like every form of international agreement, the SDGs are the result of an uneasy compromise.

The quest ahead of us is to ascertain how the SDGs can support the shift of the prevailing narrative of separation, in which humanity sees itself as separate from and above the rest of nature, to a narrative of co-evolution. As we do so, we harmonize our human activities with the continuing regeneration of life on our planet while developing our potential as humans.

Achieving the SDGs requires a profound transformation in the way we live, think and act in resonance with the living Earth. For the regenerative theorists and practitioners 'At a time of increasing global threat to the livingness of Earth, it is more important than ever to understand not just how living systems survive or even thrive, but how they stay on a progressive course toward increasing vitality, viability and potential. In other words, how they evolve' (Regenesis, 2018). This is the quest of our generation. How humanity repositions itself in time to occupy a safe and just space within planetary boundaries (Rockström et al. 2009).

Foucault (1967) would argue that in order to establish a right relationship to life, others, and oneself - one must stay close to events, experience them, be willing to be effected and affected by them. Therefore, a key question ahead of our generation is:

How can we stay close to the livingness of the Earth, ready to be effected and affected by the living planet, as we unravel the convergence of multiple crises through the SDGs framework?

\section{From sustainable to regenerative development}

The regenerative concept argues how, in an unpredictable world, one can enable the places where we live and work to thrive, going well beyond merely sustaining a precarious balance (Regenesis Group, 2017). This requires finding ways to continually, consciously regenerate ourselves and our thinking. It requires us to continually see ourselves and our place as humans in new ways, with new potential within an unending process of movement and unfoldment (Bohm, 1980).

Regenerative design is grounded in a deep understanding of the integral and interdependent nature of living systems, 
social and biotic (Mang and Reed, 2017), which informs economies that move within ecosystems processes (Milani, 2000). For instance, it is common knowledge that the SDGs will create at least 12 trillion dollars in new market opportunities by 2030 (Vali, 2017). The Goals intend to bring millions of people previously dependent on public aid, into the global economy. However, what sort of economy? Business cannot succeed in ecologies and societies that fail. Businesses are required to align new revenue opportunities with a valuegenerating capability that make both people and the rest of the natural world more strongly and more vibrantly resilient. In this context, it is crucial that social and economic decisions must coincide with ecosystem boundaries. Using natural resources efficiently within the system in regenerative loops is not only profitable but ensures the very resources on which humanity and business rely.

The carbon-intensive linear waste economy concentrated in narrow bands of the population has had its day while business models that harness environmental performance are engines of regenerative advantage. Innovation is required to balance new sustainable consumption and production patterns with the protection of terrestrial ecosystems.

We live and breathe in nested systems of intelligence and activity. While developing new strategies, services and products, a constellation of SDGs which generates multiple wins and positive side-effects to enhance the whole set of goals should be chosen. The goals are designed to interact, so integrated design means progressing them simultaneously. By doing so, our generation is changing the mindset that has created the convergence of crises.

The capacity for evolution inherent in all living systems has been central to life's ability to sustain itself for billions of years. For this reason, 'design for evolution' is a key principle of regenerative development which means that we can design and develop the intrinsic and extrinsic conditions that enable living systems to become agents of their ongoing evolution as partners in a larger co-evolution (Regenesis, 2017). In this context, dialogue with the rest of the natural world is intentionally established.

The case for adopting the SDGs as a framework is incredibly compelling. We have been asked to do something that has never been done before. Despite being a global agenda, the implementation of the SDGs implies locally adaptable, resource conserving policies, activities and products, carefully tailored to the biocultural uniqueness of each location. The role of forward-looking regenerative practitioners is key in seizing the SDGs' potential. By understanding the integral and interdependent nature of the Goals, we can gain a wholesystems perspective and become enablers of a vitality by which society, ecologies and economies can co-evolve and thrive.

\section{References}

Balmford, A., Fisher, B., Green, R.E., Naidoo, R., Strasburg, B., Turner, R.K., Rodrigues, A.S.L., 2011. Bringing ecosystem services into the real world: an operational framework for assessing the economic consequences of losing wild nature. Environ. Resour. Econ. 48, pp. 161-175.

Bohm, D., 1980. Wholeness and the Implicate Order. Routledge.

Burton, M. and Kagan C., 2000. Edge Effects, resource utilisation and community psychology. III European Conference on Community Psychology. Bergen. Norway.

Dearing, J.A et al., 2014. Safe and just operating spaces for regional social-ecological systems. Global Environmental Change 28 pp. 227-238

Denrell, J., Fang, C. and Winter, S. G., 2003. The economics of strategic opportunity. Strategic Management Journal 24, 977-990.

East, M., 2008. Ecovillages- Design at the Edge. Kosmos Journal. Spring Summer 2008.

Engels, J., 2015. Why is the Edge so Damned Important? Permaculture Research Institute.

Foucault. M., 1977. Discipline and Punish: The Birth of the Prison. Penguin Books.

New York: Pantheon Books.

Giampietro, M., Bukkens, S.G.F., Pimentel, D., 1992. Limits to Population Size: Three Scenarios of Energy Interaction Between Human Society and Ecosystem. Population and Environment. Vol.14, pp.109-131.

Guthery, F.S., and Bingham, R.L., 1999. On Leopold's principle of edge. Wildlife Society Bulletin 20(781).

Hempel, L. C., 1999. Conceptual and analytical challenges in building sustainable communities. In D. Mazmanian \& M. Kraft (Eds.), Toward sustainable communities: Transition and transformations in environmental policy. Cambridge, MIT Press.

Holmgren, D., 2011. Permaculture Principles \& Pathways Beyond Sustainability. Revised Edition. Australia.

IGBP, 2001. Amsterdam Declaration on Earth System Science. International Geosphere-Biosphere Programme, International Human Dimensions Programme on Global Environmental Change, World Climate Research Programme [ONLINE] Available at:

http://www.igbp.net/about/history/2001amsterdamdeclaratio nonearthsystemscience.4.1b8ae20512db692f2a680001312.h tml [Accessed 12 June 2020].

IONS, 2005. What the Bleep do we Know Study Guide. The Institute of Noetic Sciences and Captured Light Industries. 
Jacobs, J., 1961. The Death and Life of Great American Cities. New York: Random House.

Keepin, W., 2012. The Song of the Earth. Permanent Publications.

Kuhn, T., 1962. The Structure of Scientific Revolution. University of Chicago Press

Lovelock, J., 2003. Gaia: The living Earth. Nature. Volume 426. pp 769-770.

Lunn, J., Downing, E., and Booth, L., 2015. The Sustainable Development Goals and the post-2015 development agenda. Briefing Paper. House of Commons, Number 7291.

Macy, J., 2003. World as Lover World as Self. Parallax Press.

Mang, P. and Reed, B., 2011. Designing from place: A regenerative framework and methodology. Building Research $\&$ Information. Regenesis.

Milani, B., 2000. Designing the Green Economy. Rowman \& Littlefield Publishers

Mollison, B. C.,1990. Permaculture a practical guide for a sustainable future. Island Press.

Murphy, T. and Marvick, V., 1998. Patterning as Process. Permaculture Activist. \#39.

Raworth, K., 2017. Doughnut Economics: Seven Ways to Think Like a 21st-Century Economist. London: Random House Business.

Reed, B., 2007. Shifting from 'sustainability' to regeneration. Building Research \& Information, 35:6. 674680pp.

DOI: $\underline{10.1080 / 09613210701475753}$

Regenesis Group, 2017. The Regenerative Practitioner. Systemic Frameworks. Regenesis Group, Inc.
Rockström, J., Steffen, W., Noone K., Persson, Å., Chapin, F. S., Lambin, E., Lenton, T. M., Scheffer, M., Folke, C., Schellnhuber, H., Nykvist, B., De Wit, C. A., Hughes, T., Van der Leeuw, S., Rodhe, H., Sörlin, S., Snyder, P. K., Costanza, R., Svedin, U., Falkenmark, M., Karlberg, L., Corell, R. W., Fabry, V. J., Hansen, J., Walker, B., Liverman, D., Richardson, K., Crutzen, P., and Foley, J., 2009. Planetary boundaries: exploring the safe operating space for humanity. Ecology and Society 14(2): 32. [online] http://www.ecologyandsociety.org/vol14/iss2/art32/ [Accessed 12 June 2020].

Rockström, J., and Sachs, J. D., 2013. Sustainable Development and Planetary Boundaries. High Level Panel on the Post-2015 Development Agenda. The Sustainable Development

Steffen, W., Richardson, K., Rockström, J., Cornell, S., Fetzer, I., Bennett, E.M., Biggs, R., Carpenter, S.R., de Vries, W., de Wit, C.A., Folke, C., Gerten, D., Heinke, J., Mace, G.M., Persson, L.M., Ramanathan, V., Reyers, B., Sörlin, S. (2015): Planetary Boundaries: Guiding human development on a changing planet. Science Vol. 347, Issue 6223, 1259855.

UNEP, 2012. The 10YFP adopted at Rio+20. UNEP DTIE SCP Branch. [ONLINE] Available at:

http://www.unep.fr/scp/ [Accessed 12 June 2020].

United Nations, Resolution A/RES/70/1, 2015. Transforming our World: the 2030 Agenda for Sustainable Development. Adopted by the General Assembly on 25 September 2015. Seventieth session. Agenda items 15 and 116.

Vali, N., 2017. More than philanthropy: SDGs are a $\$ 12$ trillion opportunity for the private sector. UNDP Our Perspectives. Available at:

https://www.undp.org/content/undp/en/home/blog/2017/8/25 More-than-philanthropy-SDGs-present-an-estimated-US12-trillion-in-market-opportunities-for-private-sectorthrough-inclusive-business.html [Accessed 12 June 2020].

(C) 2020 by the author(s). This article is an open-access article distributed under the terms and conditions of the Creative Commons Attribution (CC-BY) license (http://creativecommons.org/licenses/by/4.0/). 